\title{
ACCOUNTING PROBLEMS UNDER THE EXCESS PROFITS TAX
}

\author{
WAiter A. COOPER*
}

A prominent jurist has said that taxation is an eminently practical subject-to which statement accountants add "Amen." Too often, however, our legislators, jurists and administrative authorities pay lip service to the ideal and promptly forget it in practice. Perhaps that is too broad a statement. It may, in many cases, correctly describe the result but not the attempt, because often the accounting problems or difficulties are neither visualized nor appreciated. It is understandable that such a result may be reached by those who are not, in any way, acquainted with accounting difficulties which arise in attempting to apply statutory concepts, ideal in nature, to what might be termed "fluid" accounting principles and data.

I use the term "fluid" not in the sense of uncertainty or lack of substance but to describe an ever-changing panorama. Accounting science must keep, and has kept, pace with business and changing industry and commerce. What is correct today was not accceptable five years ago, and that, in turn, was not acceptable ten years earlier.

Accounting principles and practices have had to change as business has changed, as industrial organizations have changed, as the requirements of accounting data have changed, and as laws and administrative authorities have changed-as in the case of the tax laws and the Securities and Exchange Commission requirements.

The excess profits tax law focuses more attention on these problems and difficulties than any tax law we ever have had, because it involves a heavy tax on net income in excess of certain statutory credits or exemptions, both of which are historical in nature or, as in the case of Section 722 relief claims, fictional. A correct determination necessarily requires that the needed historical accounting and other factual data be available, or that the ultimate results which may now be reflected in the accounts presently appearing in the records of corporate taxpayers reflect the result of accumulated accounting in line with what is now required for tax purposes.

In seeking to develop a taxing statute which produces what seems to be the ideal result, legislators frequently fail to take into account, probably because the difficulties are not visualized, the inability of the taxpayer or his accountant to supply the answers required. So also do our jurists, who sometimes reach what may well be a

- B.C.S., 1923, New York University. Certified Public Accountant, New York State (1924), Oklahoma (1933), Pennsylvania (1937). Chairman of the Committee on Taxation of the New York State Society of Certified Public Accountants; Chairman of the Special Committee of the Tax Foundation on Post-War Reserves; formerly Chairman of the Committee on Federal Taxation of the American Institute of Accountants. 
practical result in a given situation, but in the process lay down a principle that is impractical in many other cases.

Greater leeway is available to administrative officials who, being less rigid in their approach, can recognize these difficulties and give credence to records, statements, or even working papers, notes or other records which, retained and presented in good faith, provide the only source for the development of data which is required by legalistic concepts and historical bases but which cannot otherwise be established by normal sources of evidence. We have yet to see whether or not that will be done, but as matters now stand it remains for the administrative officials to soften the impact of impractical legislative theory. Here are some of the specific problems we face:

\section{Invested Capital Paid In}

Congress has said that one of the norms for determining profits that are not excessive shall be specified percentages of capital originally paid in to taxpayer corporations, and, where the capital that was paid in took the form of property other than cash, it is to be measured by the cost of the property, which is usually its value at the date of acquisition.

Take a simple case and disregard such frills as "property at its basis for determining loss under the law applicable to the year in which it was disposed of" if it is no longer on hand. Such property may have been paid in twenty, fifty or more years ago. When such property consisted of what might be called consumable items, such as depreciable plant assets, inventory, etc., all of which have long since been consumed in operations, we might expect to have no problem, because whatever is treated as paid-in capital somehow or other becomes a charge against accumulated earnings or surplus, so that the one item of invested capital is reduced by the amount included in the other. However, that does not necessarily follow, because in dealing with the determination of accumulated earnings one is required to reduce profits actually realized by losses or deduction's to the extent recognized for income tax purposes, and the so-called mitigation of the Statute of Limitations (Section 734) requires that there be an adjustment of the prior-year income tax liability if it was determined by treating any item entering into the determination of the invested capital in a manner inconsistent with the treatment accorded it in such determination.

Hence, in all such cases, it becomes necessary to ascertain when the consumable item was consumed and should have been treated as a deduction in determining taxable income (from I9I3 on, only). If it has not been allowed as a deduction in the year in which it should have been allowed, the taxpayer may be in position to invoke the benefits of Section 734 to obtain an adjustment of the prior year's tax liability, or else force the Treasury to incorrectly determine the accumulated earnings for the current-year invested capital computation in order to be consistently incorrect with the prior treatment.

Thus a correct determination might require a complete revaluation as of the date of acquisition many years ago of plant assets, inventories, etc., as well as a determina- 
tion of when they were consumed, even though they no longer exist and are not part of the capital with which the taxpayer corporation is now operating.

Similarly, when such permanent assets as goodwill are involved, a valuation, which may never have been made, may now be required. Furthermore, these problems apply not merely to the existing taxpayer but may apply to a series of predecessors, all of whom have long since expired but whose basis carries forward to the existing taxpayer.

Lucky is the taxpayer who has the records now available to even attempt to show its correct position. Valuations may have to be made "sight unseen" by persons who at the time had no idea of the existence of the assets they now are required to value, and will have to do that on the basis of cold, statistical data. And all too often those data are no longer available.

In the writer's own practice a number of situations have arisen in which such items as goodwill are required to be valued as of some early date and the records or other information of either the taxpayer or the predecessor are no longer available. A common method of evaluating goodwill is to predicate it on a capitalization of earnings for a period prior to acquisition. In many cases, particularly where the predecessor owner was a partnership or an individual proprietorship, records, if they were maintained at the time, cannot now be located. Sometimes old handwritten statements of net income written at the time are found at the bottom of musty old files. Such meager information attorneys may say is inadmissible evidence. In other cases the early earnings history of the present taxpayer, subsequent to the determinative date, must be used as the basis to which some yardstick of valuation must be applied to ascertain the extent to which such assets contribute to the invested capital currently in use. If a reasonable attitude in the acceptance of such data as are available is not adopted by administrative authorities, some taxpayers are going to suffer inequitable taxation.

\section{Accumulated Earnings}

Similar problems arise in connection with the determination of that portion of invested capital represented by what is described in the statute as the accumulated earnings and profits. No one as yet has attempted to define fully the term "accumulated earnings and profits," and even the statute goes no further than to indicate the treatment of certain items that enter into its determination. Where an accumulation of earnings exists, some of our problems disappear in the sense that one need not distinguish between the effect on capital and earnings of items that offset each other, as both constitute part of invested capital. Where a deficit exists, however, the problem becomes much more acute, for what enters into a deficit account is not considered in determining invested capital; but what affects paid-in capital is included in invested capital. 


\section{Base-Period Income}

Some of the problems relating to the determination of invested capital, which is one of the measures of normal profits, have been described. Equally difficult problems have arisen in connection with the determination of the average base-period net income, which is the other measure of normal profits. Here the law permits or requires the adjustment of the income correctly reflected on tax returns for items recognized as abnormal, but taxpayers were not keeping their accounts in those days in anticipation of an excess profits tax law which would call for the adjustment of abnormal items. Accountants find, therefore, that some detailed analyses, theoretically required, cannot now be made with exactness.

As an illustration, consider the case of a taxpayer who suffered a strike during the base period. A strike usually involves the incurrence of abnormal expenses, possibly in the form of additional wages, the expenses of those who attempt to work, extra costs for trucking or transportation of workers and merchandise, losses through defective work or destruction of properties or merchandise, expenses of guards and compensation paid when work cannot be performed. All such items are usually abnormal in nature and, under the law, may be added back to the actual net income, determined after deducting such charges. Very often the costs have been absorbed through general expense charges including items that are not abnormal. The wages may appear in the wages account along with normal wages; merchandise losses may be absorbed in material costs of production; and lost, non-productive time may have been absorbed in either of those classifications or through overhead. How to extract the amounts representing the abnormal expenses or losses is often a problem and, when it is impossible to develop the amounts with exactness, we must resort to estimates or apportionments. Unless administrative authorities are prepared to accept such methods, some taxpayers will be denied justice in the determination of their tax liabilities.

\section{Relief under Section 722}

Finally, we come to what may be termed the fictional feature of our excess profits $\operatorname{tax}$ law, that is, the determination of relief from burdensome taxation and undue hardship which is available under the provisions of Section 722 of the Internal Revenue Code. Here the taxpayer must reconstruct and redetermine what its income would have been during the base period if the abnormal circumstances or conditions, specified in the law as entitling a taxpayer to relief, had not existed.

To use the statutory language, the benefits of this relief are available if "the taxpayer establishes what would be a fair and just amount representing normal earnings." The word "establish" is defined in standard dictionaries as: "to fix firmly," "prove legally," or with similarly strong synonyms. If that statutory language is taken literally, how will the taxpayer ever be able to "prove legally" results or earnings which, in fact, never materialized? Obviously, such a reconstruction of earnings must be largely a matter of estimate or opinion, or even guesswork. Unless adminis- 
trative authorities approach these determinations with an open mind and with full recognition of the difficulties involved, fair results will not be obtained.

This publication will contain discussions dealing with principles of taxation in the development of tax laws or legal interpretations of what we have on our statute books. Ultimately, these technical matters will be settled by the enactment of tax legislation and the interpretation thereof by our courts. We shall be left with the problem of applying practically the resulting rules to the admissible data. The accountant can work only with what is in the records that are available to him. Unless both our courts and our administrative authorities deal with these difficulties as reasonable men-not seeking the last ounce of legal proof or evidence-no law will ever produce equitable taxation. It is heartening to note an expansion of this reasonable approach in both legislative and administrative policies. At the present writing, it must go much further, and it is the accountants' hope that as the wisdom and knowledge of the administrative organizations develop through greater experience in dealing with these problems, this tendency will continue. 